\title{
AIDS administrators plan crisis meeting over future of AZT
}

London \& Washington. Senior research administrators from both sides of the Atlantic plan to meet before the end of the month to discuss the implications of Anglo-French trial results which last week cast doubt on the usefulness of the drug AZT in treating HIV.

According to preliminary results published in The Lancet, the three-year trial, organized jointly by Britain's Medical Research Council and the French National AIDS Research Agency, has shown no evidence that treatment with AZT delays the onset of AIDS in patients known to be carrying the HIV virus.

The study was based on 1,749 patients. Some of these were given AZT from the start; the others were given a placebo until they developed symptoms of either AIDS or AIDS-related complex (ARC), when they were then switched to AZT. There was no significant difference in the rate at which AIDS progressed in the two groups; about 8 per cent in each group had died within the three years.

Scientists on both sides of the Atlantic have said that the so-called "Concorde" trial confirms what many had felt for a long time, namely that AZT taken on its own is likely to be limited in delaying the onset of AIDS. They hope that a combination of drugs including AZT - will prove more effective, impelling mutations of the virus in inconsistent directions.

But differences of opinion have emerged on the regulatory significance of the Concorde trial. Some European scientists have criticized the decision of the US Food and Drug Administration, under heavy pressure from AIDS activists, to endorse the widespread use of AZT in pre-symptomatic AIDS patients on the basis of early results from four US studies showing the drug's apparent effectiveness.

The European critics feel that the results of the latest trials justify their initial scepticism about some of the early claims made as a result of the US studies.

Tony Pinching, professor of immunology at St Bartholomew's Hospital Medical College in London, acknowledges that the US studies showed a "possible benefit" to those infected with HIV. But he argues that the benefits were "too small and too shortterm for us to know what they meant in the long-term". The results of the Concorde trial came as "a considerable shock", he says, particularly to those who had been expecting some positive outcome, however small.

In the United States, senior health administrators stressed that their advice to doctors and researchers to continue working with AZT in the immediate wake of the

Concorde results did not imply any criticism of the European study. "I have every reason to believe that this is a first rate study", says Daniel Hoth, AIDS director of the National Institute for Allergy and Infectious Diseases (NIAID). "The results need not be inconsistent with other trials. In the end we all agree that AZT is an effective drug, but only for a short period."

Hoth, who called the upcoming meeting with the Concorde group as soon as the results were published, reacted angrily to UK press criticism that previous US AZT trials had been rushed, pointing out that the trials were curtailed only because regulators judged, once AZT appeared to be inhibiting AIDS, that their continuation was unfair to patients on the placebo side of the trial.

Wellcome Foundation, which currently sells more than $£ 200$ million ( $\$ 300$ million) of AZT a year, dismissed the use of AZT on its own as "old science", but also claimed that the Concorde conclusions were not as black-and-white as they appeared. But Gregg Gonsalves of the Treatment Action Group,

\section{Rules eased for US field tests}

San Francisco. The US Department of Agriculture (USDA), ending years of debate, has relaxed regulatory supervision of field tests of six important genetically engineered crops.

A new rule published on 31 March in the Federal Register exempts the crops from the long process required for a permit and allows biotechnology companies to carry out experiments with corn, cotton, tomatoes, soybeans, tobacco and potatoes after notifying USDA in a letter and waiting 30 days. The new rule would have allowed 85 per cent of the 365 permits issued for field tests at 724 sites to have gone forward under the simpler notification.

Biotechnology executives see the plan as a substantial improvement on the present system, in which the government analyses every proposed planting in a process that can take four months. The new rule is also a clear victory for environmentalists against a proposal by the Bush administration that would have eliminated any waiting period. Terry Medley, chief of the agriculture department's biotechnology section, points out that the rule is consistent with President Bill Clinton's intent to balance economic stimulation with environmental safety.

The preamble to the rule advises the industry to expect an additional review of genetically engineered pesticides and the commercialization and marketing of foods. an AIDS activist organization in New York, said that large numbers of patients newly identified as HIV carriers were still being prescribed AZT on its own.

One matter to be discussed when the research administrators meet will be the Concorde trial's demonstration that the level of CD4 white blood cells rose significantly in patients who had been receiving AZT, even though there was no subsequent clinical benefit.

US regulatory officials have been using the level of CD4 (T-helper) cells as a surrogate measure of the progress (and alleviation) of AIDS symptoms. However, there are many in Britain who feel that the US approach, which has relied heavily on the CD4 measure in licensing other potential anti-AIDS drugs, is wrong, and that the decision to put a patient on AZT should be more broadly based, using a number of factors - including the best current estimate of likely long-term risks and benefits - rather than a simple formula.

David Dickson \& Colin Macilwain

The Food and Drug Administration has also hinted that it may revise a policy that does not at present require special safety testing or labelling for most biotechnology foods.

The new field-testing rule requires regulators to tell researchers within a month whether they can proceed. Plants used to produce drugs are not eligible for the onemonth notification. The new rule also allows the federal government to consult state officials on any regional scientific concerns.

A company may request a one-time exemption for a crop not on the list or it may ask the government to add its crop to a list of those permanently exempted from the permitting requirement. The rule abandons an earlier plan that would have allowed safety boards or state officials to help researchers make such decisions on their own.

Medley said that his agency received 84 comments from universities, states, publicinterest groups and others on the proposed rule. The Industrial Biotechnology Association says that the 30 -day plan reduces the chances that an increasing number of applications will clog the system. At the same time, it said, the new rule may help to build public trust by retaining clear federal supervision and by providing enough time for local officials and public interest groups to react to any proposed field test.

Sally Lehrman 